\section{Student Support in Higher Education 2015/2016}

\section{June 2015}

\section{Introduction}

This factsheet provides information on the different types of support available to students who are planning to study a full or part-time higher education course in 2015/2016.

\section{Student Finance}

When an individual undertakes a course at any higher education institution, they will generally be able to group their financial outgoings into two categories. These are:

- Tuition Fees and;

- Living Costs.

The Tuition Fees cover the cost of the course itself and the Living Costs also known as Maintenance Costs will cover accommodation, food, travel and any equipment needed to enable the individual to complete the course.

Financial assistance is available to most students in Wales studying a first degree and is available in a variety of forms and from a variety of organisations as long as the student meets the eligibility criteria set out for that particular scheme, grant, bursary or loan.

Student Finance Wales is a partnership organisation in Wales that provides support services to Welsh students.
Student Finance Wales is responsible for assessing students' eligibility and the Student Loans Company make payments in the form of grants and loans, on behalf of the Welsh Government. This guide aims to highlight support that is specifically available through Student Finance Wales.

Set out below is the basic eligibility criteria that all Welsh students must meet to qualify for any financial support. However, this is a complicated area and individuals should seek specialist advice from Student Finance Wales if they are unsure of their eligibility.

\section{Eligibility}

To be eligible for support from Student Finance Wales;

- individuals must meet the residency criteria;

- the course must lead to a recognised qualification;

- the higher education institution or course must be publicly funded and located in the UK.

More detailed information on eligibility can be found in the following guides produced by Student Finance Wales;

\section{- Student finance - New full-time students 2015/16 (PDF, 712KB)}

- Student loans - A guide to terms and conditions 2015/16 (PDF, 252KB) 


\section{Full Time Students}

All the loans and grants listed below will usually be paid in three instalments throughout the year.

\section{Loans}

\section{Tuition Fee Support}

Students who study at a publicly-funded university or college can be charged a maximum of $€ \mathbf{9 , 0 0 0}$ tuition fee per year.

A Tuition Fee Loan can be taken out to cover the first $\mathbf{€ 3 , 8 1 0}$ of tuition fees. However if the university or college charges more than this, students can apply for a Fee Grant of up to $\mathbf{£ 5 , 1 9 0}$ to cover the difference.

Students can choose to take the Fee Grant only. If this does not fully cover the tuition fee that is being charged, then they will need to pay the difference to the university or college themselves.

There are no restrictions on the amount private universities or colleges can charge. If the chosen course is 'designated' by the Welsh Government then students can apply for a maximum Tuition Fee Loan of $€ 6,000$ but will not be eligible for a Fee Grant

Both the Tuition Fee Loan and Fee Grant are paid directly to the university or college and are not income assessed, which means that the entitlement for these does not depend on a student's household income.

\section{Maintenance Loans}

Maintenance Loans are also available to help students with any living costs they incur whilst studying in a higher education institution. The amount of financial support a student can receive can vary depending on whether or not the loan is based on a student's household income. Just like the tuition fee loan, this loan will have to be repaid after the course has been completed and the student is earning over $€ 21,000$ a year.

Maintenance Loan (based on household income)
The maximum amounts of Maintenance Loan for new students starting in academic year 2015/16 based on household income are:

\begin{tabular}{|c|c|}
\hline $\begin{array}{c}\text { Living arrangements } \\
\text { during term-time }\end{array}$ & $\begin{array}{c}\text { Maximum Maintenance } \\
\text { Loan available }\end{array}$ \\
\hline $\begin{array}{c}\text { Living at the parental home } \\
\text { Living away from home and } \\
\text { studying at a university or } \\
\text { college outside London } \\
\text { Living away from home and } \\
\text { studying at a university or } \\
\text { college in London } \\
\text { Studying overseas }\end{array}$ & $€ 5,162$ \\
\hline
\end{tabular}

\section{Maintenance Loan (not based on household income)}

The maximum amounts of Maintenance Loan for new students starting in academic year 2015/16 not based on household income are:

\begin{tabular}{|c|c|}
\hline $\begin{array}{c}\text { Living arrangements } \\
\text { during term-time }\end{array}$ & $\begin{array}{c}\text { Maximum Maintenance } \\
\text { Loan available }\end{array}$ \\
\hline $\begin{array}{c}\text { Living at the parental home } \\
\text { Living away from home and } \\
\text { studying at a university or } \\
\text { college outside London } \\
\text { Living away from home and } \\
\text { studying at a university or } \\
\text { college in London } \\
\text { Studying overseas }\end{array}$ & $€ 4,121$ \\
\hline
\end{tabular}




\section{Grants}

\section{Welsh Government Learning Grant}

This grant aims to help students who come from families on a low income. The amount a student will receive depends on the combined total annual household income. Students with a combined total annual household income of less than $€ 50,020$ will be eligible for this grant. If the household income is $£ 18,370$ or less the student will be eligible for the full grant of $€ 5,161$. If the total household income is between $€ 18,371$ and $€ 50,020$ the student will only be eligible for a partial grant.

\begin{tabular}{|c|c|}
\hline Household Income & $\begin{array}{l}\text { Welsh Government } \\
\text { Learning Grant available }\end{array}$ \\
\hline up to $£ 18,370$ & $€ 5,161$ \\
\hline up to $€ 20,000$ & $€ 4,715$ \\
\hline up to $€ 25,000$ & $€ 3,347$ \\
\hline up to $€ 26,500$ & $€ 2,936$ \\
\hline up to $£ 30,000$ & $£ 2,099$ \\
\hline up to $€ 34,000$ & $€ 1,142$ \\
\hline up to $£ 40,000$ & $€ 734$ \\
\hline up to $£ 45,000$ & $€ 393$ \\
\hline up to $£ 50,020$ & $€ 50$ \\
\hline$£ 50,753$ and above & $€ O$ \\
\hline
\end{tabular}

Unlike the Tuition Fee and Maintenance Loans, anyone receiving this grant will not have to pay it back.

If a student receives a Welsh Government Learning Grant there will be a corresponding reduction in the amount of Maintenance Loan available to them.

\section{Special Support Grant}

The Special Support Grant is intended to help with costs such as books, course equipment and travel. The maximum amount students can get for Special Support Grant is $€ 5,161$ per year.

Unlike the Welsh Government Learning Grant, this will not affect the amount of Maintenance Loan that an individual may be entitled to. Additionally, the grant does not count as income when working out other income-related benefits or Tax Credits.

Eligibility criteria for this grant can be found on the Student Finance Wales website. Students will only be entitled to either the Welsh Government Learning Grant or the Special Support Grant as they are unable to claim for both.

For more information, or details on which grant to apply for, contact Student Finance Wales on $\mathbf{0 3 0 0}$ 2004050

\section{Part Time Students}

\section{Tuition Fee Loan}

Part-time students starting a course on or after 1 September 2014, can get a Tuition Fee Loan to help pay for the tuition fees charged by the university or college. Students can apply for a Tuition Fee Loan of up to $€ \mathbf{2 , 6 2 5}$ (studying in Wales) or $€ \mathbf{6 , 7 5 0}$ (studying elsewhere in the UK), depending on the course intensity. Students must be studying an average course intensity of at least $\mathbf{2 5 \%}$ to get a Tuition Fee Loan.

\section{Course Grant}

Students studying part time courses are also entitled to financial support in the form of a Course Grant to help toward course costs. The amount a student can claim depends on their total household income and the maximum grant available is $€ 1,155$.

Students must be studying at an average course intensity of at least $\mathbf{5 0 \%}$ to get a Course Grant. 


\section{Partial Cancellation Scheme}

Partial cancellation of the Maintenance Loan

If a student takes out a Maintenance Loan through Student Finance Wales in academic year 2015/16, they could have up to $€ 1,500$ cancelled from the student loan balance by the Welsh Government when they start repaying.

Students will not be eligible for partial cancellation if they have any outstanding charges, costs, expenses or penalties in relation to the loan or if they are in breach of the loan agreement.

More information on this scheme can be obtained by contacting Student Finance Wales on $\mathbf{0 3 0 0} 200$ 4050 or in the SFW Guide to student loans terms and conditions for 2015-16 (PDF, 253KB)

\section{Additional Support}

Not everyone's personal circumstances are the same and some people may require additional support to begin or continue their studies. Anyone in receipt of any of the grants listed in this section will not need to repay them, and they will usually be paid in three instalments throughout the year. The amounts referred to relate to the maximum amounts available for full-time students. Lower amounts are available for part-time students.

\section{Childcare Grant}

The Childcare Grant is available to students with children under the age of 15 , or 17 if the child has special educational needs, who are studying a full time course. It is intended to help pay towards any childcare costs that are incurred while they are studying. Like the other grants the amount an individual will receive will depend on their household income.

\section{Eligible students will be able to use this grant to} cover up to $85 \%$ of their childcare costs as long as the children are being cared for by a registered approved childcare provider, centre or foster carer.
The maximum a student can receive for one child is $£ 161.50$ per week. If the student has two or more children the maximum they will be entitled to is €274.55 per week.

\section{Parents Learning Allowance}

The Parents Learning Allowance is available to students studying full time course and is intended to help students who have dependent children.

Students can receive a maximum of $€ 1,557$ per year to help with costs related to their course. The amount an individual will receive will depend on their household income. The Parents Learning Allowance should not affect any other benefits the student may be entitled to.

\section{Adult Dependants Grant}

The Adult Dependants Grant is available to students studying full-time. The grant is intended to help students who have an adult family member to support financially, who is not their child and would not be able to cope financially without the support of the student.

The amount an individual will receive will depend on their household income and the maximum a student can receive is $€ 2,732$ per year.

Students can only apply for this grant for one adult dependant. If they have more than one adult dependant they can still only receive Adult Dependants Grant once.

More detailed information on the Childcare Grant, Parents Learning Allowance and the Adult Dependants Grant can be found in the following guide produced by Student Finance Wales;

- Extra help - Dependants' Grants 2015/16 (PDF, 1.34MB) 


\section{Disabled Students' Allowances (DSAs)}

Disabled Students' Allowances are available to students on full time or part time courses. They can be used to help with any extra costs that arise as a result of the student's disability, health condition or learning difficulty.

There are four different types of allowance available. All of these allowances except for one has a maximum amount a student could be entitled too. Students will need to be assessed to find out which allowance would best suit their needs.

- Information relating to the four allowances are set out below;

- Non-medical helper allowance ( $€ 21,181$ maximum per year);

- Specialist equipment allowance ( $₫ 5,332$ maximum for the entire course);

- Other disability-related expenditure allowance ( $€ 1,785$ maximum per year);

- Disability-related travel allowance (Reasonable spending on additional travel costs incurred as a result of the condition).

The amount of DSA a student can get does not depend on personal income, or that of parents or partners. More detailed information on the DSAs can be found in the following guide produced by the Student Finance Wales;

\section{- Extra help - Disabled Students' Allowances in 2015/16 (PDF, 465KB)}

\section{Travel Grant}

If a student is attending a clinical placement in the UK or studying abroad as part of the course then they may be eligible for a Travel Grant to help with travel expenses.

Students can get a grant towards reasonable costs for travel to and from:
- the place in the UK where the clinical training takes place; or

- the country a student has to go to if studying abroad

The Travel Grant will only cover reasonable travel expenses and students will be expected to pay the first $€ 303$ themselves.

\section{Financial Contingency Funds}

Higher Education Institutions also operate their own Financial Contingency Fund (sometimes referred to as a Student Hardship fund) in order to provide discretionary financial help:

- to students who need extra financial help to meet particular costs which are not already being met from other sources of funding;

- to provide emergency payments for unexpected crises;

- to intervene where a student may be considering leaving higher education because of unexpected financial problems

Assistance is subject to a number of eligibility criteria with priority given to certain groups, however there is no automatic entitlement to an award, which is decided by each individual institution at its discretion.

Further information on Financial Contingency Funds can be obtained from individual university student support or money advice centres. 


\section{Research Service}

The Research Service has produced a separate factsheet entitled Higher Education - financial support for adult and postgraduate learners. This guide aims to signpost sources of information relating to Undergraduate and Postgraduate Study. It also contains information on databases, charities, trusts and foundation that may provide individuals with financial assistance.

- Higher Education - financial support for adult and postgraduate learners (PDF, 233KB)

View our full range of publications on the Assembly website.

\section{Specialist Advice and Support}

\section{Student Finance Wales}

Student Finance Wales provides information and support to individuals who wish to undertake a course that will lead to a recognised qualification in higher education institutions in Wales.

\section{For more information:}

Tel: 03002004050

Web: www.studentfinancewales.co.uk 